\title{
最近の歯学
}

\section{2. 高齢者齿科}

\author{
高齢者の体表面加算平均心電困と局所麻酔 \\ 東京医科歯科大学歯学部高齢者歯科学講座 河辺 \\ 覚, 大渡 凡人, 海野 雅浩, 長尾 正憲
}

局所麻酔は霜科治療における偶発症の誘因の一つで ある。一方, 高秢者は心筋梗塞などの基礎疾患を多く 合併しているだけでなく, 心筋の予備力が低下してい るために, 局所麻酔により心筋の虚血性変化や不整脈 などが誘発されやすいことが予測される。高齢者にこ のような心筋虚血や不整脈が生じると, 若年者では生 じないような血行動態の悪化を招いて，五次的に致死 的不整脈を引き起こす可能性もある。

近年，心電図記録の技術的進歩に伴い，これまで見 逃されていた心電図中の微小電位の解析が可能となっ た。この微小電位は, 体表面加算平均心電図法により 得られ, 体表心蔵微小電位と呼ばれ, 心室筋の情報と して用いられている ${ }^{1)}$ QQRS 波形中の体表心臟微小電 位は, 心筋の虚血性変化などの組織性状変化の有用な 指標といわれており，QRS 終末部に検出される体表心 蔵微小電位は, 心室遅延電位と呼ばれ, 心臓突然死の 原因となるリエントリ一性心室性不整脈の基質を示す 指標として用いられている。そこで, QRS 波形中，お よび QRS 終末部の体表心臓微小電位を指標として, 高齿者における局所麻酔の心筋に及ほす影響と致死的 不整脈の基質の有無について検討した。

70 歳以上の観血的処置を予定する患者を，陳旧性心 筋梗塞群および非陳旧性心筋梗塞群の 2 群に分け, 局 所麻醉前後で体表面加算平均心電図を記録した。解析 には, 心室遅延電位の指標として, 40-250Hzのfiltered QRS duration (以下 $\mathrm{f}-\mathrm{QRS}$ ) 扔よび $\mathrm{QRS}$ 終末部 $40 \mathrm{~ms}$ の平均電圧（root mean square 40 以下 RMS 40) を 用いた。室遅延電位陽性の基準は, RMS 40 が $20 \mu \mathrm{V}$ 未満とした。同様に, $\mathrm{f}-\mathrm{QRS}$ の異常值は $120 \mathrm{~ms}$ 以上と したささらに, QRS 波形の高周波微小電位の指標とし て, $150-250 \mathrm{~Hz}$ の全 QRS 波形の平均電圧 (root mean square total 以下RMST) を計測した。

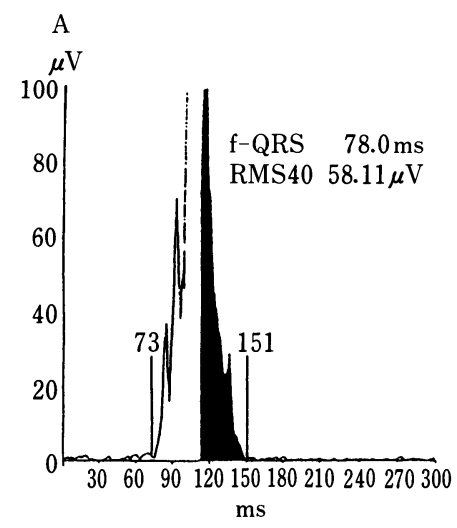

その結果，心室遅延電位陽性例は，陳旧性心筋梗塞 群, 非陳旧性心筋梗塞群にそれぞれ2 例認められた(図 1)。しかし, 局所麻酔により心室性不整脈の発生頻度 に明らかな変化は認められなかった。一方, RMSTは 非陳旧性心筋梗塞群で局所麻醉により有意に低下した (表 1 )。

以上のことから，高齢歯科患者においては，陳旧性 心筋梗塞の有無に関わらず, 致死的不整脈の可能性の ある患者が歯科外来を訪れており，また局所麻酔によ り心筋の虚血性変化が生じる可能性が高いことを考慮 する必要があると思われた。今後, 体表面加算平均心 電図は歯科治療における心筋梗塞者のスクリーニング 検查としての応用が期待される。

\section{文献}

1) Simson, M. B. : Use of signals in the terminal QRS complex to identify patients with ventricular tachycardia after myocardial infarction. Circulation. 64:235-242, 1981.

2）河辺 覚：高齢者の体表面加算平均心電図に及ほ す局所麻醉の影響. 日歯麻誌 $22: 335-349$, 1993.

表 1 RMST の変化

\begin{tabular}{lll}
\hline \hline \multicolumn{3}{c}{ 陳旧性心筋梗塞群 非陳旧性心筋梗塞群 } \\
\hline RMST $(\mu \mathrm{V})$ & & \\
局所麻酔前 & $8.58 \pm 1.01$ & $9.13 \pm 0.86$ \\
局所麻酔後 & $8.27 \pm 0.99$ & $8.68 \pm 0.84^{* *}$ \\
\hline
\end{tabular}

B

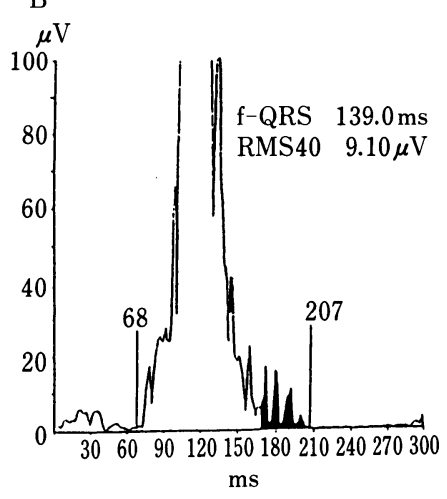

図 1 体表面加算平均心電困の 2 例

A : 心室遅延電位陰性例, B : 心室遅延電位陽性例 